\title{
MODEL PENGEMBANGAN PERPUSTAKAAN DALAM MEMBUDAYAKAN MINAT BACA MAHASISWA
}

\author{
MS. Sumantri
}

\begin{abstract}
Reading interest can be develop through planning, organizing, directing, and evaluating a program of creating and developing reading interest in the community as well as at school. This study attempted to develop reading interest of University Student at the State University of Jakarta, particularly at PGSD FIP UNJ. Creating a model of developing library to establish reading culture, this study applied the model to the student. At the end of the study it was found that the model is effective to develop students' reading interest and habbit and also improve their learning achievement simultaneously.
\end{abstract}

Key words: reading interest, reading culture, library, development model, learning achievement.

\section{Abstrak}

Minat baca dapat dikembangkan melalui perencanaan, pelaksanaan, pengendalian, dan penilaian suatu program peningkatan minat baca melalui perpustakaan yang ada di tengah-tengah masyarakat atau di sekolah. Penelitian ini mengembangkan sebuah model pengembangan perpustakaan dalam membudayakan minat baca mahasiswa di PGSD FIP UNJ. Pada akhir penelitian ditemukan, model yang dikembangkan ternyata dapat meingkatkan minat dan kebiasaan membaca mahasiswa serta meningkatkan hasil belajar secara bersamaan.

Kata-kata kunci: minat baca, budaya baca, perpustakaan, pengembangan model, hasil belajar.

\section{PENDAHULUAN}

Membaca adalah proses untuk memperoleh pengertian dari kombinasi beberapa huruf dan kata. Membaca merupakan kemampuan dan keterampilan untuk membuat suatu penafsiran terhadap bahan yang dibaca. Kepandaian membaca tidak hanya diartikan dengan menginterpretasikan huruf-huruf, gambargambar, dan angka-angka saja, akan tetapi yang lebih luas daripada itu ialah kemampuan seseorang untuk dapat memahami makna dari sesuatu yang dibacanya. Karena itulah membaca merupakan kegiatan intelektual yang dapat mendatangkan pandangan, sikap, dan tindakan yang positif. Fungsi dari membaca itu sendiri adalah dapat membuka cakrawala pengetahuan menjadi lebih luas, pengetahuan menjadi bertambah banyak sehingga menjadi manusia yang tidak picik.

Pembinaan minat baca merupakan proses yang berkelanjutan untuk membantu individu agar minat bacanya tumbuh dan berkembang. Dengan demikian, tujuan umum pembinaan minat baca adalah mengembangkan minat baca masyarakat dan beberapa tujuan khusus yang dalam pencapaiannya perlu kerja sama dengan berbagai pihak yang terkait.
Pada dasarnya, pembinaan minat baca mempunyai tiga fungsi utama, yaitu sebagai sumber kegiatan, pedoman pelaksanaan kegiatan, dan tolok ukur atau parameter keberhasilan upaya menumbuhkembangkan minat baca.

Saat ini disadari atau tidak disadari, minat baca mahasiswa khususnya di Jurusan PGSD FIP UNJ sangat rendah. Hal ini dibuktikan dengan jumlah pengunjung rata-rata perhari 50-70 orang dari jumlah mahasiswa 1.200 orang. Sedangkan jumlah peminjam rata-rata perhari 30-50 orang dari jumlah mahasiswa 1.200 orang.

Berangkat dari uraian tersebut di atas, maka dapat dirumuskan masalah sebagai berikut, "Bagaimana model pengembangan perpustakaan PGSD FIP UNJ dalam membudayakan minat baca mahasiswa?".

\section{KAJIAN PUSTAKA}

\section{Hakikat Membaca}

Ada tiga kelompok yang mendefinisikan tentang hakikat membaca yaitu kelompok pertama dengan tokohnya Jennings (1965), membuat definisi membaca sebagai tafsiran terhadap pengalaman secara umum, selain itu, membaca biasanya akan dimulai dengan pengenalan terhadap peristiwa yang berulang-ulang 
datang, seperti matahari dan bulan yang terbit setiap hari. Kelompok kedua dengan Flesch (1955) sebagai tokohnya, mendefinisikan membaca sebagai kegiatan memperoleh makna dari berbagai gabungan huruf, seperti seorang anak yang diajari mengenal makna yang dimiliki oleh setiap huruf akan sampai pada kemampuan membaca. Kelompok ketiga dengan Horn (1937) sebagai tokohnya, mendefinisikan membaca sebagai kegiatan yang meliputi berbagai proses penyempurnaan dan pelestarian makna melalui penggunaan media alat tulis. Ketiga pendekatan tersebut merupakan hasil kerja keras para ahli bahasa yang mengkaji masalah membaca dengan sudut pandang yang berbeda.

\section{Pendekatan dalam Membaca}

Pendekatan yang diterapkan dalam studi membaca untuk menghasilkan teori membaca berkisar pada tiga macam pendekatan. Pendekatan konseptual yang meliputi bermacam-macam metodologi pendekatan yang berangkat dari suatu konsepsi tentang membaca dan berkesudahan dengan suatu model tertentu tentang proses membaca. Pendekatan kedua adalah pendekatan empirikal yang bertolak dari pengalaman serta penghayatan proses membaca, baik dari penyusunan teori itu sendiri maupun dari orangorang lain yang dijadikan subjek penelitian. Sedangkan, pendekatan eksperimental sebagai pendekatan yang berangkat dari suatu eksperimen tertentu. Eksperimen ini ditujukan terhadap seperangkat perilaku membaca yang dapat diamati, dikaji, dan kemudian dianalisis untuk disimpulkan menjadi suatu teori membaca tertentu.

Tokoh perintis dalam pendekatan konseptual ialah Kennet S. Goodman. Menurut pandangannya, proses membaca pada hakikatnya adalah proses komunikasi, yaitu komunikasi antara pembaca dengan turunan tertulis (bacaan) yang dibacanya. Namun, pendekatan tersebut direvisi karena disadari banyak kelemahannya. Sebagai penggantinya dipakailah teori Transformasi Generatif temuan Noam Chomsky sebagai acuan kerja untuk memberikan proses membaca dalam bentuk suatu model yang dikenal sebagai model membaca Goodmen (The Godman Model Of Reading). Model ini menekankan bahwa membaca pada hakikatnya adalah seperangkat proses recording, decoding, dan encoding yang berakhir pada pemahaman atau komprehensif.

Teori membaca yang memanfaatkan pendekatan empirikal banyak ragamnya. Seperti halnya teori yang memandang membaca sebagai proses berpikir, perangkat keterampilan, kegiatan visual, serta pengalaman bahasa.
Pada pendekatan ketiga, yaitu pendekatan eksperimental memandang membaca sebagai proses atau kegiatan menangkap makna dari bacaan. Beberapa penemuan yang dapat dimanfaatkan untuk kepentingan pengajaran membaca sebagai penemuanpenemuan proses mempersepsi makna, yang meliputi persepsi atau pemahaman akan makna materi bacaan dan menganalisis pola bentukan bahasa bacaan. Persepsi yang kuat atau baik terhadap makna bahasa bacaan sebagai hasil menghayati dan menganalisis bahasa bacaan itu akan membuat pembaca memiliki ingatan yang baik pula terhadap makna bacaan itu.

Selanjutnya, pendekatan eksperimental dianggap sebagai langkah penemuan mengenai pembentukan konsep dalam membaca, yaitu makna simbolik tentang hal-hal yang direspon pembaca meliputi persepsi dan konsep. Persepsi yang baik terhadap makna bahasa bacaan dan menghasilkan konsep yang baik pula tentang makna bahasa bacaan itu. Konsep yang abstrak sifatnya tentang makna material bahasa bacaan terbentuk berdasarkan konsepkonsep yang konkrit dan tingkat intelegensi pembaca. Selain itu juga sebagai pengembangan konsep tentang makna bahasa bacaan dapat dibina dengan menyiapkan program pengajaran membaca yang baik.

Penemuan-penemuan lainnya yang dikembangkan melalui pendekatan eksperimental adalah tentang penerapan penguasaan bahasa pembaca dalam proses memahami makna meliputi jumlah kosakata yang dikuasai, luas dan dalamnya ragam makna kata yang dikuasainya, dan mapannya penguasaan terhadap kaidah-kaidah bahasa, serta baiknya penguasaan tentang tata penulisan bahasa.

\section{Pentingnya Membaca}

Kemampuan membaca merupakan wahana utama yang dapat menjunjung martabat suatu bangsa ke kedudukannya yang paling tinggi. Hal itu sudah menjadi keyakinan yang tidak diragukan lagi dalam era informasi yang tengah dijalani. Kata "iqra" (bacalah) tidak akan diletakkan Allah SWT pada awal kalimat perintah-Nya yang pertama jika makna yang dikandungnya itu tidak sedemikian pentingnya. Farr, Fay \& Negley (1978), seorang peneliti dalam bidang pendidikan membaca juga pernah membuat pernyataan betapa pentingnya pendidikan membaca itu dalam sebuah kalimat yang berbunyi "Reading is the heart of education".

Pascaindustri ini lebih tepat disebut era media massa, atau era sistem komunikasi dan informasi, atau era sibernetik. Dalam upaya mempertahankan diri di era sibernetika ini, masyarakat nusantara tidak mungkin mengabaikan masalah-masalah yang berkaitan 
erat dengan kemahiran baca tulis. Berbagai tujuan pendidikan nasional hanya akan tergapai oleh anggota masyarakat yang literate. Masyarakat literate ialah masyarakat yang melek wacana, yang sanggup menganalisis, kemudian membuat sintesis dan evaluasi tentang informasi tercetak sebelum mengambil keputusan berdasarkan kemampuan nalar dan intuisinya.

Hanya masyarakat literate yang mampu menjadi masyarakat beriman dan bertakwa terhadap Allah SWT, berbudi pekerti luhur, berkepribadian yang kuat, berdisiplin, bekerja keras dan berkualitas, tangguh serta bertanggung jawab, mandiri, cerdas, serta sehat jasmani dan rohani. Maka tak mengherankan sejak belasan abad, Alquran mengingatkan manusia untuk menjadi anggota masyarakat yang literate. Pada mulanya, pendidikan membaca itu diarahkan pada masalah-masalah keagamaan. Sesudah itu menyusul periode pendidikan membaca yang bersifat nasionalistik-moralistik. Periode ketiga menekankan pendidikan membaca yang harus menghasilkan lulusan yang memiliki inteligensi yang tinggi. Periode keempat mengarahkan pendidikan membaca pada masalah nilai budaya. Kemudian, pendidikan membaca itu ditandai oleh adanya penekanan terhadap penelitian ilmiah yang disusul oleh periode penelitian yang dilakukan secara mendalam serta aplikatif, dengan jalan memperhatikan penerapan hasil yang dicapai dalam penelitian tersebut. Sejarah umum pendidikan membaca diwarnai juga oleh konflik internasional. Terjadilah interaksi antara abad atom dan pendidikan membaca yang melahirkan berbagai pernyataan konseptual tentang hakikat membaca. Membaca merupakan proses berpikir yang mempunyai kedudukan utama dalam semua mata ajar sekolah. Membaca harus mempunyai tujuan tertentu serta pertumbuhan serta perkembangan membaca itu dipengaruhi oleh banyak faktor.

Di samping guru yang meyakini proses membaca bottom up, ada kelompok guru yang berpendapat bahwa proses membaca itu top down. Kelompok guru ini memusatkan perhatiannya kepada pembaca. Para guru ini berpendapat bahwa pembaca memulai kegiatannya tidak dengan kepala yang kosong. Pada setiap saat, guru siap dengan penga-lamannya tentang bahasa dan informasi mengenai dunia sekitarnya. Pembaca yang mahir selalu membawa informasi yang dimilikinya ke dalam proses membaca. Kelompok pembaca seperti ini tidak mempunyai banyak perhatian terhadap kata-kata atau bagian kata yang dibacanya. Pada waktu membaca, perhatian tertuju pada hal-hal yang bisa ditebak maknanya berdasarkan pengalamannya. Perkiraan guru bisa merupakan pengujian hipotesis. Para guru membuktikan berbagai perkiraannya sejak awal sampai akhir kegiatan membacanya dengan menggunakan strategi inquiry. Pada proses membaca top down, makna ditentukan oleh pembaca sebagai faktor yang dominan. Pada zaman kebanjiran informasi, model membaca yang perlu lebih banyak digunakan ialah model top down.

\section{Membaca sebagai Proses Perkembangan Keteram- pilan}

Telah dilukiskan bahwa membaca itu merupakan latihan yang sangat kompleks yang sangat tergantung pada bermacam-macam faktor. Sifat proses perkembangan keterampilan itu dapat dijelaskan sebagai keterampilan itu objektif. Satu di antara hal yang mula-mula disadari waktu meneliti proses perkembangan keterampilan membaca ialah bersifat objektif. Hal tersebut dipandang objekif karena dalam perkembangannya tidak tergantung pada materi, metode, ataupun tingkatan-tingkatan akademis. Pandangan seperti itu tidak mempunyai arti penolakan terhadap adanya keterampilan membaca dalam proses yang sangat erat kaitannya. Satu bagian terpenting dari proses perkembangan itu ialah identifikasi keterampilan yang akan diajarkan. Jika keterampilan tertentu sudah dapat diidentifikasi, satu dari sejumlah metode yang demikian banyak yang akan dipakai sudah dapat digunakan untuk mengajar anak. Seorang anak mungkin akan dapat belajar melalui program visual; anak yang lain akan merasakan kemudahan belajar membaca itu melalui penglihatan; dan yang lain melalui kinestik.

Faktor kedua adalah Keterampilan itu mempunyai sifat berlanjut. Meskipun keterampilan itu tidak terikat pada tingkatan kelas anak, namun kaitannya tetap tampak. Ini tidak berarti bahwa guru harus mengajarkan konsonan awal sebelum mengajarkan konsonan akhir, tanda titik sebelum tanda tanya, atau membaca fakta sebelum membaca untuk mencari ide utama. Anak akan mampu mencari materi sumber secara mandiri setelah menguasi keterampilan-keterampilan prasyarat.

Selanjutnya faktor yang ketiga disebut sebagai Keterampilan itu digeneralisasikan. Di samping objektif dan bertahap, keterampilan itu bersifat tergeneralisasikan. Keterampilan dasar dalam membaca dapat digeneralisasikan sehingga anak yang telah menguasai keterampilan tersebut dituntut untuk menerapkannya kapan saja dan di mana saja jika situasinya menghendaki pengeneralisasian itu. Jika anak telah menguasai cara memahami kata secara mandiri, baginya tidak akan merupakan masalah di mana pun 
kata itu berada, baik dalam teks matematika, buku latihan geografi, ataupun di dalam sebuah novel.

Dasar proses perkembangan keterampilan ialah perkembangan konsep. Hal tersebut mulai dengan pengalaman anak yang mula-mula sekali yang terus berkembang seumur hidupnya. Perkembangan konsep itu merupakan prasyarat untuk membaca, sama juga halnya untuk menyimak dan berbicara. Pengembangan konsep itu merupakan bank pengetahuan yang bagi anak berfungsi sebagai tempat menyimpan dan mengambil informasi secara terus-menerus. Dalam pertumbuhannya itu anak-anak tumbuh dan berubah, demikian juga pebendaharaan konsepnya akan terus tumbuh dan berubah-ubah.

Pertumbuhan dan perubahan konsep anak banyak bergantung pada latar belakang pengalamannya. Anak yang mempunyai semacam lingkungan saja, tingkat komunikasi yang itu-itu juga, serta pengalaman yang sejenis, akan tehambat perkembangan kosakatanya. Anak mengenal makna kata-kata itu melalui pendengaran penggunaannya dan upaya menggunakannya sendiri.

Tahap perkembangan yang kedua merupakan pengenalan dan identifikasi. Pada waktu anak membina dasar-dasar konsep yang pertama, anak mulai pula menghubungkan konsep-konsepnya itu dengan stimuli tertentu.

Tahapan ketiga perkembangan itu merupakan interpretasi mengenai informasi.

\section{Perpustakaan Sebagai Sumber Belajar}

Disadari bahwa dalam usaha mengembangkan perkuliahan yang berkualitas diperlukan adanya kecukupan fasilitas, alat, dan bahan ajar yang memungkinkan mahasiswa dapat memperoleh sumber pengetahuan yang memadai.

Perpustakaan adalah kumpulan materi tercetak dan media noncetak dan atau sumber informasi dalam komputer yang disusun secara sistematis untuk digunakan pemakai. (International Federation of Library Association and Institutions).

Perpustakaan: 1) tempat, gedung, ruang yang disediakan untuk pemeliharaan dan pendayagunaan koleksi buku, dan sebagainya; serta 2) koleksi buku, majalah dan bahan kepustakaan lainnya yang disimpan untuk dibaca, dipelajari, dan dibicarakan. (Pusat Bahasa Departemen Pendidikan Nasional, 2002)

Harold's Librarians' Glossary edisi ke 8, 1995 memberikan beberapa arti: 1) koleksi buku atau materi lain yang disimpan untuk bacaan, pembelajaran, dan konsultasi; 2) tempat, bangunan, ruang yang dikhususkan bagi koleksi buku dsb.; 3) sejumlah buku yang diterbitkan oleh penerbit dengan judul yang komprehensif dan biasanya memiliki karakter khusus seperti subj ek, cara penjilidan, atau tipografi; 4) koleksi film, foto dan media non-buku lain termasuk pita, cakram, pita atau cakram komputer, dan program; 5) (penggunaan khusus dalam pemrograman komputer) koleksi program atau perintah yang dipakai secara rutin dalam proses komputasi.

Perpustakaan adalah institusi/lembaga pengelola koleksi karya tulis, cetak dan atau rekam sebagai sumber informasi ilmu pengetahuan, teknologi dan seni yang diatur dan ditata menurut sistem yang baku dan didayagunakan untuk keperluan pendidikan, penelitian, informasi, dan rekreasi bagi masyarakat (Hanson, 1998).

Perpustakaan diartikan sebuah ruangan atau gedung yang digunakan untuk menyimpan buku dan terbitan lainnya yang biasanya disimpan menurut tata susunan tertentu yang digunakan pembaca bukan untuk dijual (Walton, 1991 ).

Perpustakaan adalah suatu unit kerja yang berupa tempat menyimpan koleksi bahan pustaka yang diatur secara sistematis dan dapat digunakan oleh pemakainya sebagai sumber informasi.

Dengan pesatnya kemajuan dibidang teknologi pembelajaran maka diperlukan layanan individual atau layanan sumber belajar yang bervariasi seperti halnya ketersediaan buku, multimedia pendidikan yang optimal, selajutnya buku, bahan sumber belajar, media pembelajaran pada umumnya disediakan oleh unit khusus di suatu lembaga yang disebut perpustakaan.

Menurut Hadiat (1980:25), perpustakaan merupakan bagian dari pusat sumber belajar yang mencakup bahan-bahan, peralatan, dan lingkungan belajar. Dengan perpustakaan secara umum bertujuan memberikan atau meyediakan pelayanan informasi instruksional seperti buku-buku bahan cetak, produksi, dan multimedia pendidikan.

Perpustakaan di perguruan tinggi bukan hanya sebagai tempat koleksi buku saja, tetapi perpustakaan harus menjadikan tempat sumber belajar yang dinamis. Buku-buku yang harus tersedia di perpustakaan adalah buku-buku yang berhubungan dengan proses pembelajaran dan aneka bahan perkuliahan di perguruan tinggi.

Perpustakaan sangat memegang peranan penting dalam meningkatkan kemampuan akademik mahasiswa terutama didukung oleh kualitas pelayanan yang paripurna baik perangkat keras maupun perangkat lunak seperti halnya ketersediaan teknologi informasi. 
Kelengkapan ruang perpustakaan hendaknya terdapat: ruang baca, minimal dapat menampung 20 orang, ruang staf perpustakaan yang berhubungan dengan perbaikan buku, pengadministrasian buku, perbaikan penjilidan, dan sebagainya.

Lebih lanjut Hadiat (1980:28) menegaskan bahwa kelengkapan lainnya yang penting adalah ketersediaan ruang foto copy dan alat reprografi, ruang rak buku, ruang WC khusus untuk keperluan perpustakaan, ruang gudang untuk menyimpan bukubuku yang belum disirkulasikan atau buku-buku yang sudah tidak digunakan lagi, ruang khusus untuk menyimpan AVA termasuk perangkat computer.

Menurut Nasution (1982:18) perpustakaan berfungsi sebagai bentuk belajar mahasiswa yang diistilahkan dengan Resources Based Learning, belajar berdasarkan sumber bukan suatu yang berdiri sendiri, melainkan berkaitan dengan sejumlah perubahanperubahan pembinaan kurikulum. Sumber yang sejak lama dikenal adalah buku-buku hingga saat ini buku sangat memegang peranan penting. Oleh sebab itu ahli perpustakaan menjadi penting dalam belajar berbasis sumber.

Belajar berbasis sumber adalah salah salah cara mahasiswa belajar di perpustakaan baik secara individu maupun berkelompok. Jadi bukan cara konvensional di mana dosen menyampaikan bahan ajar di kepada mahasiswa di depan kelas.

Perpustakaan yang memadai menurut Heinich dkk (1996:54) memiliki aneka media komunikasi informasi selain buku-buku antara lain media yang tidak diproyeksikan, media audio, media video, media berbasis komputer, dan multimedia kit. Sedangkan menurut Knapp (1996:124), pentingnya kompetensi pustakawan terkadang membutuhkan keterampilan untuk melatih mahasiswanya dalam membantu mengakses informasi menjadi lebih efektif dan efisien seperti halnya melayani penyediaan informasi dalam penyusunan makalah, tugas-tugas dosen, dan lainlain. Hubungannya dengan akses dan ketersediaan artikel jurnal, sistem katalog, kamus elektronik, ensiklopedia, dan lain-lain.

\section{METODOLOGI PENELITIAN}

\section{Metode}

Sesuai dengan tujuan penelitian yang dirumuskan, maka metode yang digunakan dalam penelitian ini adalah metode deskriptif. Metode deskriptif adalah metode penelitian yang menggunakan observasi, wawancara, atau angket mengenai keadaan sekarang ini, mengenai subjek yang diteliti (Ruseffendi, 2001). Metode ini digunakan dengan pertimbangan bahwa masalah-masalah yang diteliti adalah masalah yang ada pada masa sekarang atau gejala-gejala yang tampak dewasa ini.

Metode deskriptif ditujukan untuk mengetahui fenomena-fenomena sosial yang terjadi di masyarakat dan berlangsung pada masa sekarang juga untuk mencapai tujuan penelitian yang berupa deskripsi atau gambaran dari masalah yang diteliti.

Secara jelas Surachmad (1998: 140) mengemukakan bahwa metode deskriptif mempunyai ciri: 1) merumuskan ciri pada masalah-masalah yang ada pada masa sekarang atau pada masalah-masalah yang aktual, dan 2) data yang dikumpulkan mula-mula disusun, dijelaskan kemudian dianalisis (karena itulah metode ini sering disebut metode analisis). Jadi, metode ini menekankan pada tujuan untuk mengumpulkan informasi mengenai suatu gejala pada saat penelitian.

Penelitian ini akan mendeskripsikan tentang model pengembangan perpustakaan jurusan PGSD FIP UNJ dalam membudayakan minat baca mahasiswa.

\section{Teknik Pengumpulan Data}

Teknik pengumpulan data yang dipergunakan dalam penelitian ini yaitu cara-cara yang digunakan untuk memecahkan masalah penelitian, sesuai dengan instrumen yang akan digunakan dalam memperoleh data. Sedangkan, pengumpulan data merupakan suatu proses untuk menghimpun data yang relevan serta akan memberi gambaran dari aspek yang diteliti. Berdasarkan pada masalah penelitian, maka alat atau metode yang digunakan dalam teknik pengumpulan data adalah sebagai berikut angket, wawancara, observasi, studi dokumentasi, dan studi kepustakaan.

\section{HASIL DAN PEMBAHASAN}

\section{Analisis Data}

Adapun langkah-langkah dalam menganalisis data adalah sebagai berikut:

\section{a. Seleksi Instrumen}

Seleksi instrumen ini mencakup proses pengecekan dan seleksi data. Seleksi instrumen ini dilakukan sebagai langkah awal dalam proses pengolahan data. Hal ini dilakukan untuk mengetahui kelengkapan alat pengumpul berupa angket yang disebarkan. Kelengkapan angket tersebut ditandai oleh angket yang kembali dengan jumlah yang sama seperti semula dan angket tersebut memenuhi syarat untuk 
diolah agar dapat menjawab permasalahan penelitian.

Angket yang dapat diolah harus memenuhi persyaratan sebagai berikut (1) pengisian angket sesuai dengan petunjuk yang telah ditentukan; (2) pengisian angket jelas dan tidak meragukan; dan (3) setiap lembaran angket lengkap, tidak ada bagian yang hilang atau rusak

Hasil seleksi data dapat dilihat pada tabel berikut.

Tabel 1. Rekapitulasi Penyebaran Angket Upaya Pengelola Perpustakaan dalam Meningkatkan Minat Baca Mahasiswa PGSD FIP UNJ

\begin{tabular}{|c|c|c|c|}
\hline \multirow{2}{*}{$\begin{array}{c}\text { Jumlah } \\
\text { Sampel }\end{array}$} & \multicolumn{3}{|c|}{ Frekuensi } \\
\cline { 2 - 4 } & Disebar & Terkumpul & $\begin{array}{c}\text { Dapat } \\
\text { diolah }\end{array}$ \\
\hline 260 & 260 & 260 & 260 \\
\hline
\end{tabular}

\section{Penyajian Data Hasil Penelitian}

a. Identitas Responden

Gambaran identitas responden pada hasil pengolahan data ini dibatasi pada jenis kelamin, usia, dan pekerjaan. Berdasarkan data yang diperoleh dari peggolongan responden berdasarkan jenis kelamin, diperoleh data, sebagai berikut.

Tabel 2. Penggolongan Responden Berdasarkan Jenis Kelamin

\begin{tabular}{|l|l|c|c|}
\hline No & $\begin{array}{c}\text { Jenis } \\
\text { Kelamin }\end{array}$ & Frekuensi & Persentase \\
\hline 1 & Laki-laki & 90 & 34.6 \\
\hline 2 & Perempuan & 170 & 65.4 \\
\hline & Jumlah & 260 & $100 \%$ \\
\hline
\end{tabular}

Dari tabel 2, data penggolongan responden menurut jenis kelamin di atas dapat terlihat bahwa antara responden perempuan dan responden laki-laki memiliki jumlah yang tidak merata. Jumlah responden didominasi oleh perempuan dan laki-laki lebih sedikit. Persentase responden dengan jenis kelamin perempuan lebih dari setengahnya, yaitu $65.4 \%$ dari jumlah keseluruhan responden. Sedangkan persentase responden dengan jenis kelamin laki-laki hanya sebanyak 32,36 \% dari jumlah keseluruhan responden. Penggolongan responden menurut usia dapat dilihat pada tabel berikut:

Tabel 3. Penggolongan Responden Berdasarkan Usia

\begin{tabular}{|c|c|c|c|}
\hline No & Usia & Frekuensi & Persentase \\
\hline 1 & $18-28$ & 225 & 86.5 \\
\hline 2 & $28-38$ & 23 & 8.9 \\
\hline 3 & $38-48$ & 12 & 4.6 \\
\hline \multicolumn{2}{|c|}{ Jumlah } & 260 & $100 \%$ \\
\hline
\end{tabular}

Sumber: Hasil Penelitian tahun 2009.
Berdasarkan data yang diperoleh, terlihat rentang usia anggota perpustakaan yang menjadi responden dalam penelitian ini golongan usianya tidak merata. Secara umum, dari keseluruhan responden yaitu sebanyak $86.5 \%$ anggota perpustakaan PGSD FIP UNJ yang menjadi responden berada dalam rentang usia antara 18-28 tahun. Sedangkan, $8.9 \%$ responden berada dalam rentang usia antara $28-$ 38 tahun. Sementara itu, sisanya sekitar $4.6 \%$ responden berada dalam rentang usia antara 38-48 tahun.

b. Tanggapan responden

Tanggapan responden terhadap keberadaan perpustakaan PGSD FIP UNJ dalam meningkatkan minat baca mahasiswa tampak pada tabel berikut:

Tabel 4. Keberadaan Perpustakaan dalam Meningkatkan Minat Baca Mahasiswa

\begin{tabular}{|c|c|c|}
\hline Alternatif Jawaban & Frekuensi & Persentase \\
\hline Sangat membantu & 230 & 88.5 \\
\hline Cukup membantu & 20 & 7.7 \\
\hline Tidak membantu & 10 & 3.8 \\
\hline Jumlah & 260 & $100 \%$ \\
\hline
\end{tabular}

Sumber : Hasil Penelitian tahun 2009.

Tabel di atas memberikan gambaran mengenai tanggapan responden tentang keberadaan perpustakaan dalam meningkatkan minat baca mahasiswa.

Berdasarkan hasil penelitian, dapat dilihat bahwa keberadaan perpustakaan PGSD FIP UNJ sangat membantu mahasiswa dalam meningkatkan minat baca mahasiswa PGSD FIP UNJ, hal ini dapat terlihat pada tabel 4 mengenai tanggapan responden terhadap keberadaan perpustakaan dalam membantu meningkatkan minat baca mahasiswa.

Dari tabel tersebut terlihat bahwa $88.5 \%$ dari sampel yang diambil menyatakan bahwa dengan kehadiran perpustakaan PGSD FIP UNJ mahasiswa merasa sangat terbantu dalam meningkatkan minat baca mahasiswa. Sebanyak 7.7\% menyatakan cukup membantu dalam meningkatkan minat baca mereka, dan $3.8 \%$ tidak membantu mahasiswa dalam meningkatkan minat baca.

Tanggapan responden tentang waktu kunjung ke perpustakaan tampak pada tabel berikut:

Tabel 5. Waktu Kunjung ke Perpustakaan PerMinggu

\begin{tabular}{|c|c|c|}
\hline $\begin{array}{c}\text { Alternatif } \\
\text { Jawaban }\end{array}$ & Frekuensi & Persentase \\
\hline Enam Kali & 223 & 85.8 \\
\hline
\end{tabular}




\begin{tabular}{|l|c|c|}
\hline $\begin{array}{c}\text { Alternatif } \\
\text { Jawaban }\end{array}$ & Frekuensi & Persentase \\
\hline Lima Kali & 12 & 4.6 \\
\hline Empat Kali & 15 & 5.8 \\
\hline Tiga Kali & 10 & 3.8 \\
\hline Jumlah & $\mathbf{2 6 0}$ & $\mathbf{1 0 0} \%$ \\
\hline
\end{tabular}

Sumber: Hasil Penelitian tahun 2009.

Tabel di atas memberikan gambaran mengenai tanggapan responden tentang waktu yang responden luangkan untuk berkunjung ke perpustakaan di dalam satu minggu.

Berdasarkan hasil pengolahan data tabel diatas, dapat dilihat bahwa sebagian besar responden yaitu sebanyak $85.8 \%$ mengunjungi perpustakaan sebanyak enam kali dalam satu minggu. Ini berarti menunjukkan intensitas kunjungan mahasiswa sangat tinggi.

Tabel responden tentang lama waktu kunjungan ke perpustakaan tampak pada tabel berikut:

Tabel 6. Lama Waktu Kunjungan ke Perpustakaan

\begin{tabular}{|c|c|c|}
\hline Alternatif & Frekuensi & Persentase \\
\hline Empat jam & 223 & 85.8 \\
\hline Tiga jam & 23 & 8.8 \\
\hline Dua jam & 14 & 5.4 \\
\hline Jumlah & $\mathbf{2 6 0}$ & $\mathbf{1 0 0} \%$ \\
\hline
\end{tabular}

Sumber : Hasil Penelitian tahun 2009.

Tabel di atas memberikan gambaran mengenai tanggapan responden tentang lama waktu yang responden habiskan saat berkunjung ke perpustakaan.

Berdasarkan hasil pengolahan data pada tabel di atas, dapat dilihat bahwa sebagian besar responden yaitu sebanyak $85.8 \%$ meluangkan waktunya selama empat jam setiap berkunjung ke perpustakaan PGSD FIP UNJ. Tanggapan responden tentang buku yang paling diminati tampak pada tabel berikut.

Tabel 7. Buku yang Paling Banyak Diminati

\begin{tabular}{|l|c|c|}
\hline \multicolumn{1}{|c|}{ Alternatif Jawaban } & Frekuensi & Persentase \\
\hline Buku Cerita / Fiksi & 20 & 7.7 \\
\hline $\begin{array}{l}\text { Buku kependidikan/ } \\
\text { pelajaran ke SD-an }\end{array}$ & 233 & 89.6 \\
\hline $\begin{array}{l}\text { Buku yang berkaitan } \\
\text { dengan teknik dan } \\
\text { pertanian }\end{array}$ & 7 & 2.7 \\
\hline \multicolumn{1}{|c|}{ Jumlah } & 260 & $100 \%$ \\
\hline
\end{tabular}

Sumber : Hasil Penelitian tahun 2009.

Tabel di atas memberikan gambaran mengenai tanggapan responden tentang buku koleksi perpustakaan yang paling banyak diminati oleh responden.
Dari data di atas, dapat dilihat bahwa koleksi perpustakaan yang paling banyak diminati oleh responden adalah buku pelajaran atau kependidikan. Yaitu sebanyak 89.6\% dari jumlah keseluruhan responden.

Tanggapan responden terhadap waktu kunjungan perpustakaan yang disediakan oleh pengelola tampak pada tabel berikut:

Tabel 8. Waktu Kunjungan Perpustakaan

\begin{tabular}{|l|c|c|}
\hline \multicolumn{1}{|c|}{ Alternatif Jawaban } & Frekuensi & Persentase \\
\hline $\begin{array}{l}\text { Waktu yang } \\
\text { disediakan sudah } \\
\text { sesuai dengan jam } \\
\text { kerja }\end{array}$ & 230 & 88.5 \\
\hline $\begin{array}{l}\text { Waktu yang } \\
\text { disediakan belum } \\
\text { terjadwal }\end{array}$ & 5 & 1.9 \\
\hline $\begin{array}{l}\text { Waktu yang } \\
\text { disediakan sangat } \\
\text { singkat }\end{array}$ & 25 & 9.6 \\
\hline \multicolumn{1}{|c|}{ Jumlah } & 260 & $100 \%$ \\
\hline
\end{tabular}

Sumber : Hasil Penelitian tahun 2009.

Dari tabel yang disajikan di atas, dapat dilihat bahwa lebih banyak responden yang menyatakan bahwa waktu kunjungan yang disediakan oleh perpustakaan sudah sesuai dengan jam kerja yaitu sebanyak $88.5 \%$ responden. Mengenai waktu kunjungan, waktu yang sudah disediakan oleh pengelola perpustakaan sudah baik. Hal ini dapat dilihat dari tanggapan responden sebanyak $88.5 \%$. Responden menyatakan sudah merasa puas karena waktu kunjungan yang disediakan sudah sesuai dengan jam kerja, yaitu di mulai dari pukul 08.00 sampai dengan 17.00 WIB.

Tanggapan responden terhadap kelengkapan koleksi perpustakaan tampak pada tabel berikut:

Tabel 9. Kelengkapan Buku-buku/Sumber Bacaan

\begin{tabular}{|l|c|c|}
\hline \multicolumn{1}{|c|}{ Alternatif Jawaban } & Frekuensi & Persentase \\
\hline $\begin{array}{l}\text { Lengkap dan } \\
\text { memadai }\end{array}$ & 17 & 6.6 \\
\hline $\begin{array}{l}\text { Cukup lengkap, setiap } \\
\text { buku yang } \\
\text { dibutuhkan tersedia }\end{array}$ & 200 & 76.9 \\
\hline $\begin{array}{l}\text { Kurang lengkap, tidak } \\
\text { semua buku yang } \\
\text { dibutuhkan }\end{array}$ & 43 & 16.5 \\
\hline \multicolumn{1}{|c|}{ Jumlah } & 260 & $100 \%$ \\
\hline
\end{tabular}

Sumber : Hasil Penelitian tahun 2009.

Tabel di atas menyajikan gambaran data yang didapat dari responden mengenai kelengkapan koleksi perpustakaan. Dari tabel tersebut dapat dilihat bahwa 
sebanyak $76.9 \%$ responden menyatakan bahwa koleksi perpustakaan cukup lengkap, karena setiap buku yang dibutuhkan tersedia di perpustakaan ini. Koleksi yang terdapat di perpustakaan PGSD FIP UNJ berasal dari sumbangan PHK-A, Hibah DIA-BERMTU, sumbangan mahasiswa Pendidikan Dasar (Dikdas), dan pembelian dari Jurusan PGSD FIP UNJ.

Tabel 10. Kondisi Fisik

\begin{tabular}{|l|c|c|}
\hline \multicolumn{1}{|c|}{ Alternatif Jawaban } & Frekuensi & Persentase \\
\hline $\begin{array}{l}\text { Kondusif untuk } \\
\text { dipergunakan }\end{array}$ & 250 & 96.2 \\
\hline $\begin{array}{l}\text { Kurang layak untuk } \\
\text { dipergunakan }\end{array}$ & 10 & 3.8 \\
\hline $\begin{array}{l}\text { Menghawatirkan } \\
\text { untuk dipergunakan }\end{array}$ & 0 & 0 \\
\hline \multicolumn{1}{|c|}{ Jumlah } & 260 & $100 \%$ \\
\hline
\end{tabular}

Sumber : Hasil Penelitian tahun 2009.

Tabel di atas menyajikan data mengenai tanggapan responden tentang kondisi fisik perpustakaan. Pada tabel tersebut dapat dilihat bahwa lebih banyak responden yang menyatakan bahwa kondisi fisik perpustakaan kondusif untuk dipergunakan yaitu sebanyak 98,91\% respoden. Tanggapan responden terhadap sarana perpustakaan tampak pada tabel berikut:

Tabel 11. Sarana Perpustakaan

\begin{tabular}{|c|r|r|}
\hline Alternatif Jawaban & \multicolumn{1}{|c|}{ Frekuensi } & \multicolumn{1}{c|}{ Persentase } \\
\hline Lengkap dan memadai & 98 & 37.7 \\
\hline $\begin{array}{c}\text { Cukup lengkap, setiap } \\
\text { sarana yang dibutuhkan } \\
\text { tersedia }\end{array}$ & 127 & 48.8 \\
\hline $\begin{array}{c}\text { Kurang lengkap, tidak } \\
\text { semua sarana yang } \\
\text { dibutuhkan }\end{array}$ & 35 & 13.5 \\
\hline Jumlah & 260 & $100 \%$ \\
\hline
\end{tabular}

Sumber : Hasil Penelitian tahun 2009.

Tabel di atas memberikan gambaran tentang tanggapan responden mengenai sarana perpustakaan. Sebanyak $48.8 \%$ responden menyatakan bahwa sarana yang ada di perpustakaan cukup memadai karena setiap sarana yang dibutuhkan oleh responden tersedia di perpustakaan ini.

Tabel 12. Ruangan Baca di Perpustakaan

\begin{tabular}{|l|c|c|}
\hline Alternatif Jawaban & Frekuensi & Persentase \\
\hline $\begin{array}{l}\text { Penataan ruang } \\
\text { baca kondusif }\end{array}$ & 245 & 94.2 \\
\hline $\begin{array}{l}\text { Cukup nyaman, } \\
\text { karena ruangan luas }\end{array}$ & 10 & 3.9 \\
\hline $\begin{array}{l}\text { Tidak nyaman, } \\
\text { karena ruangan } \\
\text { sempit }\end{array}$ & 5 & 1.9 \\
\hline \multicolumn{1}{|c|}{ Jumlah } & 260 & $100 \%$ \\
\hline
\end{tabular}

Sumber : Hasil Penelitian tahun 2009.
Data pada tabel di atas memberikan gambaran mengenai tanggapan responden tentang ruangan baca yang ada di perpustakaan. Responden yang menyatakan bahwa ruangan baca yang ada di perpustakaan cukup nyaman karena ruangannya kondusif adalah sebanyak $94.2 \%$ responden.

\section{Tabel 13. Lokasi Perpustakaan}

\begin{tabular}{|l|c|c|}
\hline \multicolumn{1}{|c|}{ Alternatif Jawaban } & Frekuensi & Persentase \\
\hline $\begin{array}{l}\text { Strategis/mudah } \\
\text { dijangkau }\end{array}$ & 255 & 98.1 \\
\hline Jauh dari kampus & 0 & 0 \\
\hline Susah dijangkau & 5 & 1.9 \\
\hline \multicolumn{1}{|c|}{ Jumlah } & 260 & $100 \%$ \\
\hline
\end{tabular}

Sumber : Hasil Penelitian tahun 2009.

Tabel di atas menyajikan data mengenai tanggapan responden terhadap lokasi perpustakaan. Sebagian besar responden menyatakan bahwa lokasi perpustakaan strategis/mudah dijangkau oleh responden adalah sebanyak $98.1 \%$ responden.

Tabel 14. Sumberdaya Pengelola Perpustakaan

\begin{tabular}{|l|c|c|}
\hline \multicolumn{1}{|c|}{ Alternatif Jawaban } & Frekuensi & Persentase \\
\hline $\begin{array}{l}\text { Sumberdaya terlalu } \\
\text { banyak }\end{array}$ & 5 & 1.9 \\
\hline Sumberdaya kurang & 253 & 98.1 \\
\hline Sumberdaya cukup & 0 & 0 \\
\hline \multicolumn{1}{|c|}{ Jumlah } & 260 & $100 \%$ \\
\hline
\end{tabular}

Sumber: Hasil Penelitian tahun 2009.

Tabel di atas memberikan gambaran tentang tanggapan responden mengenai sumber daya yang mengelola perpustakaan. Sebanyak $98.1 \%$ responden menyatakan bahwa sumber daya pengelola perpustakaan PGSD FIP UNJ sangat kurang.

Tabel 15. Sistem Pelayanan Perpustakaan

\begin{tabular}{|l|c|c|}
\hline \multicolumn{1}{|c|}{$\begin{array}{c}\text { Alternatif } \\
\text { Jawaban }\end{array}$} & Frekuensi & Persentase \\
\hline $\begin{array}{l}\text { Menggunakan } \\
\text { komputer }\end{array}$ & 7 & 2.7 \\
\hline $\begin{array}{l}\text { Tidak ada sistem } \\
\text { pelayanan }\end{array}$ & 3 & 1.2 \\
\hline $\begin{array}{l}\text { Sistem pelayanan } \\
\text { dilakukan } \\
\text { dengan manual }\end{array}$ & 250 & 96.1 \\
\hline \multicolumn{1}{|c|}{ Jumlah } & 260 & $100 \%$ \\
\hline
\end{tabular}

Sumber : Hasil Penelitian tahun 2009.

Tabel di atas memberikan gambaran mengenai tanggapan responden terhadap sistem pelayanan yang dilakukan oleh pengelola perpustakaan. Dari tabel data yang disajikan di atas dapat dilihat bahwa sebanyak $96.1 \%$ responden menyatakan bahwa sistem 
pelayanan yang dilakukan oleh pengelola perpustakaan masih menggunakan sistem pelayanan yang dilakukan dengan cara manual.

Tanggapan responden terhadap pelayanan sirkulasi tampak pada tabel berikut:

Tabel 16. Pelayanan Sirkulasi Perpustakaan

\begin{tabular}{|l|c|c|}
\hline \multicolumn{1}{|c|}{ Alternatif Jawaban } & Frekuensi & Persentase \\
\hline $\begin{array}{l}\text { Selalu } \\
\text { memberikaninformasi } \\
\text { tentang perpustakaan }\end{array}$ & 244 & 93.8 \\
\hline $\begin{array}{l}\text { Memberikan } \\
\text { informasi jika hanya } \\
\text { diminta }\end{array}$ & 10 & 3.8 \\
\hline $\begin{array}{l}\text { Tidak pernah } \\
\text { memberikan } \\
\text { informasi }\end{array}$ & 6 & 2.4 \\
\hline \multicolumn{1}{|c|}{ Jumlah } & 260 & $100 \%$ \\
\hline
\end{tabular}

Sumber : Hasil Penelitian tahun 2009.

Tabel di atas memberikan gambaran mengenai tanggapan responden terhadap pelayanan sirkulasi yang dilakukan oleh pengelola perpustakaan PGSD FIP UNJ. Dari tabel terlihat bahwa pelayanannya menyenangkan dengan $98.1 \%$ jawaban responden.

\begin{tabular}{|c|c|c|c|c|}
\hline \multicolumn{2}{|c|}{ Alternatif Jawaban } & Frekuensi & Persentase & \\
\hline \multirow{2}{*}{$\begin{array}{l}\text { Tugas Dari Dosen } \\
\text { kuliah }\end{array}$} & Altern & latif Jawaban & Frêküensi & Persentase \\
\hline & Koleks & & 178 & \multirow[t]{3}{*}{68.5} \\
\hline \multicolumn{2}{|c|}{ Diskusi kelompok perpus } & takaan 78 ang & 30 & \\
\hline \multicolumn{2}{|c|}{ Belajar komputer beraga } & $\mathrm{m} \quad 50$ & 19.2 & \\
\hline \multirow[t]{4}{*}{ Jumlah } & Progra & 260 & $2300 \%$ & \multirow[t]{2}{*}{8.8} \\
\hline & \multicolumn{2}{|c|}{$\begin{array}{l}\text { perpustakaan yang } \\
\text { menarik dan } \\
\text { menyenangkan }\end{array}$} & & \\
\hline & \multicolumn{2}{|c|}{$\begin{array}{l}\text { Sarana, prasarana } \\
\text { dan pelayanan yang } \\
\text { nyaman }\end{array}$} & 59 & 22.7 \\
\hline & \multicolumn{2}{|c|}{ Jumlah } & 260 & $100 \%$ \\
\hline
\end{tabular}

Sumber : Hasil Penelitian tahun 2009.

Data pada tabel di atas memberikan gambaran mengenai tanggapan responden terhadap pelayanan informasi dari pengelola perpustakaan PGSD FIP UNJ. Dari tabel di atas dapat dilihat bahwa sebanyak 93.8\% responden menyatakan bahwa pengelola perpustakaan selalu memberikan informasi-informasi tentang perpustakaan, dan memberikan informasi yang aktual juga.

Tanggapan responden terhadap faktor pendukung dalam meningkatkan minat baca tampak pada tabel berikut:
Tabel 18. Faktor Pendukung Meningkatkan Minat Baca

\begin{tabular}{|l|c|c|}
\hline Alternatif Jawaban & Frekuensi & Persentase \\
\hline $\begin{array}{l}\text { Koleksi } \\
\text { perpustakaan yang } \\
\text { beragam }\end{array}$ & 178 & 68.5 \\
\hline $\begin{array}{l}\text { Program } \\
\text { perpustakaan yang } \\
\text { menarik dan } \\
\text { menyenangkan }\end{array}$ & 23 & 8.8 \\
\hline $\begin{array}{l}\text { Sarana, prasarana } \\
\text { dan pelayanan yang } \\
\text { nyaman }\end{array}$ & 59 & 22.7 \\
\hline \multicolumn{1}{|c|}{ Jumlah } & 260 & $100 \%$ \\
\hline
\end{tabular}

Sumber : Hasil Penelitian tahun 2009.

Tabel di atas menyajikan data mengenai tanggapan responden terhadap faktor yang dapat mendukung meningkatkan minat baca responden. Sebanyak $68.5 \%$ menyatakan bahwa koleksi perpustakaan yang terdapat di PGSD FIP UNJ bukunya beragam.

Tabel 19. Program yang Dapat Meningkatkan Minat Baca

Sumber : Hasil Penelitian tahun 2009.

Tabel di atas memberikan gambaran mengenai tanggapan responden tentang program perpustakaan yang dapat meningkatkan minat baca responden. Dari tabel tersebut dapat dilihat bahwa lebih banyak responden yang merasa bahwa minat bacanya meningkat. Dengan adanya pemberian tugas dari dosen mata kuliah, hal itu menyulut mahasiswa PGSD FIP UNJ untuk mencari sumber referensi ke perpustakaan.

Tanggapan responden terhadap faktor penghambat minat baca tampak pada tabel berikut:

Tabel 20. Faktor Penghambat Minat Baca

\begin{tabular}{|l|c|c|}
\hline Alternatif Jawaban & Frekuensi & Persentase \\
\hline Karena kesibukan & 125 & 48.1 \\
\hline $\begin{array}{l}\text { Karena malas } \\
\text { membaca buku }\end{array}$ & 102 & 39.2 \\
\hline $\begin{array}{l}\text { Karena tidak punya } \\
\text { buku }\end{array}$ & 33 & 12.7 \\
\hline \multicolumn{1}{|c|}{ Jumlah } & 260 & $100 \%$ \\
\hline
\end{tabular}

Sumber : Hasil Penelitian tahun 2009. 
Tabel di atas memberikan gambaran mengenai tanggapan responden tentang faktor yang menjadi penghambat minat baca responden. Dari tabel tersebut dapat dilihat bahwa responden yang menyatakan faktor penghambat minat bacanya adalah karena kesibukan sebanyak $48.1 \%$ responden.

Tanggapan responden jika ada permasalahan di perpustakaan tampak pada tabel berikut:

Tabel 21. Tanggapan Responden Jika ada Permasalahan di Perpustakaan

\begin{tabular}{|l|c|c|}
\hline \multicolumn{1}{|c|}{ Alternatif Jawaban } & Frekuensi & Persentase \\
\hline $\begin{array}{l}\text { Memberikan usulan } \\
\text { perbaikan }\end{array}$ & 149 & 57.3 \\
\hline $\begin{array}{l}\text { Turut memberikan } \\
\text { solusi }\end{array}$ & 98 & 37.7 \\
\hline Membiarkan saja & 13 & 5.0 \\
\hline \multicolumn{1}{|c|}{ Jumlah } & 260 & $100 \%$ \\
\hline
\end{tabular}

Sumber : Hasil Penelitian tahun 2009.

Tabel di atas memberikan gambaran mengenai tanggapan responden tentang sikap yang akan responden lakukan jika ada permasalahan dalam pengelolaan perpustakaan. Dari tabel data yang disajikan di atas, dapat dilihat bahwa dari keseluruhan responden sebanyak $57.3 \%$ menyatakan memberikan usulan perbaikan dalam rangka meningkatkan minat baca mahasiswa PGSD FIP UNJ.

\section{Hasil Penelitian}

Dari hasil wawancara dengan pengelola perpustakaan, bahwa upaya-upaya yang dilakukan pengelola perpustakaan untuk meningkatkan minat baca anggotanya adalah dalam bentuk nonpembelajaran dan pembelajaran.

Upaya yang berupa non pembelajaran yaitu berupa peningkatan mutu perpustakaan yang meliputi mutu koleksi, sarana, prasarana, serta layanan terhadap pengguna perpustakaan PGSD FIP UNJ.

Peningkatan mutu koleksi dilakukan oleh pengelola perpustakaan dengan cara mengadakan bahan bacaan atau koleksi perpustakaan yang sesuai dengan kebutuhan para pengguna perpustakaan. Upaya lainnya yaitu menambah jumlah atau kuantitas dari koleksi yang dimiliki oleh perpustakaan dengan memperhatikan kualitasnya. Dengan begitu koleksi yang dimiliki oleh perpustakaan menjadi beragam. Melalui keberagaman koleksi, jumlah koleksi yang banyak serta kualitas koleksi yang tinggi diharapkan dapat memberikan informasi yang cukup bagi pengguna perpustakaan, dan dapat menumbuhkan minat baca anggota perpustakaan khususnya bagi mahasiswa PGSD FIP UNJ.
Berdasarkan temuan penelitian yang merupakan bagian dari langkah model pengembangan, yaitu analisis kebutuhan yang digagas dalam beberapa pelaksanaan hibah-hibah yang diperoleh jurusan PGSD melalui analisis kekuatan, kelemahan, ancaman, dan peluang. Berdasarkan data survey yaitu jenis kelamin, usia, peran perpustakaan dalam membantu mendorong minat baca, pengelolaan perpustakaan, buku yang banyak diminati, program yang dapat meningkatkan minat baca, faktor penghambat, dan tanggapan responden atas permasalahan di perpustakaan PGSD sebagian besar diperoleh skor sikap positif terhadap pengelolaan perpustakaan PGSD FIP UNJ. Selanjutnya, dapat dipaparkan bahwa penerapan pengembangan perpustakaan PGSD, sebagai berikut.

\section{1) Penerapan Model Pengembangan Perpustakaan}

a. Adanya perpustakaan yang memadai.

b. Adanya koleksi yang memadai.

c. Penciptaan lingkungan yang kondusif.

d. Promosi minat baca.

e. Melakukan Lomba Menulis.

f. Pelaksanaan program bimbingan perpustakaan (awal kuliah).

g. Keterlibatan dalam pengelolaan perpustakaan.

2) Upaya-upaya yang dilakukan Perpustakaan PGSD FIP UNJ dalam Menciptakan Minat Baca Mahasiswa

Agar mahasiswa gemar membaca, maka upaya yang sudah diterapkan dan dikembangkan pengelola perpustakaan PGSD FIP UNJ, sebagai berikut.

a. Perbaikan sarana dan prasarana ruang perpustakaan.

b. Pemasangan CCTV, AC, dan kipas angin.

c. Pemasangan fasilitas jaringan internet.

d. Mengadakan seminar tentang manajemen perpustakaan PGSD FIP UNJ.

e. Menambah Sumber Daya Manusia sebagai pengelola perpustakaan PGSD FIP UNJ.

f. Pelatihan teknis pengelolaan perpustakaan terhadap dua orang oleh staf perpustakaan pusat UNJ.

g. Menambah koleksi perpustakaan PGSD FIP UNJ melalui pembelian, hibah PHK-A, dan hibah DIA BERMUTU dan Hibah PPG.

Dengan demikian, peran perpustakaan kampus sangat signifikan dalam mencerdaskan masyarakat penggunanya terutama dalam membudayakan minat baca. Perpustakaan kampus akan maksimal jika didukung oleh pihak pimpinan program studi. Fasilitas perpustakaan program studi yang baik, membuat mahasiswa bisa dan terbiasa belajar dengan 
baik.

Sinergi antara mahasiswa dan pustakawan, akan berbuah prestasi bagi siswa serta kinerja yang baik bagi pustakawan. Dengan koleksi uptodate yang terus berganti, mahasiswa menjadi kaya akan wawasan, ilmu pengetahuan, informasi, serta menjadi mahasiswa pintar yang mempunyai segudang prestasi. Mahasiswa yang senang dan sering memanfaatkan perpustakaan sebagai penyedia jasa informasi dan ilmu pengetahuan, akan terbantu dalam mewujudkan prestasi dan cita-cita pendidikannya.

\section{PENUTUP}

\section{Kesimpulan}

Dalam meningkatkan minat baca masyarakat terdapat beberapa faktor yang dapat menjadi pendorong dan penghambat baik itu faktor internal maupun faktor eksternal.

a. Faktor pendorong

1. Internal

Adanya keinginan dari dalam diri masyarakat sendiri untuk mengubah ke arah yang lebih baik dengan memanfaatkan waktu luang untuk datang ke perpustakaan PGSD FIP UNJ.

\section{Eksternal}

Adanya perpustakaan dengan koleksi yang beragam yang berasal dari pembelian Jurusan PGSD FIP UNJ, sumbangan hibah PHK-A, hibah DIABERMUTU, dan sumbangan dari mahasiswa DIKDAS. b. Faktor penghambat

1. Internal

Faktor penghambat dalam meningkatkan minat baca masyarakat adalah karena kemalasan mahasiswa dalam membaca buku. Hal itu disebabkan oleh kesibukan dalam melakukan kegiatan rutin seharihari, serta banyak yang tidak mempunyai buku.

2. Eksternal

Keberadaan perpustakaan cukup strategis, yaitu berada di kampus PGSD FIP UNJ, jalan Setiabudi No I Jakarta Selatan. Namun, bagi mahasiswa yang berkuliah di Halimun jaraknya sangat jauh. Hal itu menjadi faktor penghambat tersendiri dalam meningkatkan minat bacanya. Hal lain adalah belum semua dosen PGSD mendorong mahasiswanya untuk memanfaatkan perpustakaan sebagai bagian dari proses pembelajaran.

2. Saran

Berdasarkan kesimpulan tersebut di atas, penulis mengangkat tiga pokok masalah, sebagai berikut.

a. Bagi pemerintah, bahwa pemerintah dalam hal ini
Kementerian Pendidikan Nasional melalui Direktorat Pendidikan Tinggi haruslah banyak memberikan hibah-hibah kepada Jurusan/Program Studi yang baru seperti PGSD berupa buku-buku pembelajaran bagi mahasiswa.

b. Bagi Ketua Jurusan PGSD FIP UNJ, hendaknya memberikan dukungan penuh kepada pengelola perpustakaan PGSD FIP UNJ dalam rangka meningkatkan kualitas perpustakaan.

c. Pengelola perpustakaan PGSD FIP UNJ, hendaknya, sebagai berikut.

1) Lebih sering mengadakan kegiatan-kegiatan yang dilaksanakan di perpustakaan seperti penyuluhan tentang keberadaan perpustakaan.

2) Mengadakan seminar, dan lomba tentang perpustakaan sebagai upaya untuk meningkatkan jumlah kunjungan mahasiswa sehingga minat baca mahasiswa tinggi.

3) Pengelola mempertahankan dan lebih meningkatkan serta memaksimalkan pengelolaan layanan untuk memberikan layanan terbaik bagi pemakai perpustakaan.

4) Pengelola lebih meningkatkan kerjasama dengan masyarakat untuk bersama-sama dalam menumbuhkan minat baca masyarakat.

\section{DAFTAR PUSTAKA}

Aminuddin, R. (2003). Teori belajar dan pembelajaran. Jakarta: Uhamka Press

Arsyad, A. (2002). Media pembelajaran. Jakarta: Raja Grafindo Persada

Hadiat. (1981) Pusat sumber belajar dan perananya dalam LPTK. Proyek Pengembangan Kependidikan Guru. Jakarta: Kemendiknas.

Hanson, T. (1998). The uses of resources. London: Cox Nyman Ltd.

Heinich, et. al. (1989). Instructional media. New York: MacMillan Publishing Company.

Knapp, L. R. \& Glenn, A. D. (1996). Restructuring schools with technology. Boston: Prentice Hall.

LPTK. (1990). Lokakarya administrator LPTK I. Makalah. Jakarta

Mills, G. E. (2003). Action research. Ohio: Merrill Prentice Hall.

Nasution, S. (1982) Berbagai pendekatan dalam proses belajar mengajar. Jakarta: Bina Aksara.

Pusat Bahasa Departemen Pendidikan Nasional. 2002. Kamus besar bahasa Indonesia. Jakarta: Balai Pustaka

Sanjaya, W. (2006). Strategi pembelajaran berorientasi standar proses pendidikan. Jakarta: Kencana. 
Tim Pelatih Proyek PGSM. (1999). Penelitian tindakan kelas. Jakarta: Kemendiknas

Walton. J. (1994). Resource and resources centre. London: Robert Mac \& Company.

Zainal, A. (2007). Penelitian tindakan kelas. Bandung: Yarama Widya.

\section{KETERANGAN PENULIS}

M Syarif. Sumantri lahir pada tanggal 15 Mei 1961. Saat ini aktif sebagai Dosen PGSD FIP UNJ dan Sekretaris Program Dikdas/PAUD Pasca Sarjana UNJ. 